Coca, Estevan Leopoldo de Freitas. Territorialidades camponesas nos tipos de assentamentos rurais do Território Cantuquiriguaçu, Estado de Paraná, Brasil. GeoGraphos. [En línea]. Alicante: Grupo Interdisciplinario de Estudios Críticos y de América Latina (GIECRYAL) de la Universidad de Alicante, 16 de marzo de 2013, vol. 4, no 48, p. 378-403. [ISSN: 2173-1276].

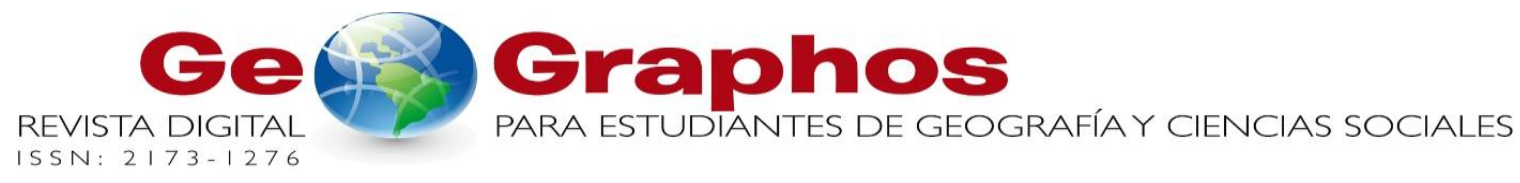

<http://web.ua.es/revista-geographos-giecryal>

Vol. 4. No 48

Año 2013

\title{
TERRITORIALIDADES CAMPONESAS NOS TIPOS DE ASSENTAMENTOS RURAIS DO TERRITÓRIO CANTUQUIRIGUAÇU, ESTADO DO PARANÁ, BRASIL
}

\author{
Estevan Leopoldo de Freitas Coca \\ Doutorando em Geografia - FCT/Unesp - Presidente Prudente (São Paulo, Brasil) \\ Correio eletrônico: estevanleopoldo@yahoo.com.br
}

Recibido: 2 de enero de 2013. Devuelto para revisión: 16 de enero de 2013.

Aceptado: 16 de marzo de 2013.

\section{RESUMO}

No Brasil, os assentamentos rurais são a principal manifestação da reforma agrária. Eles são implantados pelos governos federal, estadual ou municipal e atendem aos mais variados tipos de camponeses e territórios. Ao mesmo tempo em que garantem terra àqueles que ainda não a possuem também servem de referência para a luta pela terra realizada por outros camponeses. Neste artigo, abordamos alguns elementos da variedade dessas políticas ao destacarmos as territorialidades dos tipos de assentamentos do Território Cantuquiriguaçu, que fica no estado do Paraná. Estudamos três tipos de assentamentos: o Projeto de Colonização (PC), o Projeto de Assentamento Federal (PA) e o Projeto de Reassentamento de Atingidos por Barragens (PRB). Eles são implantados visando atender demandas dos camponeses na luta pela manutenção do seu modo de vida e produção. Mostramos como neles estão assentados camponeses com distintas identidades, constituindo diferentes territorialidades.

Palavras-chave: Reforma Agrária, Assentamentos rurais, Campesinato. 


\title{
TERRITORIALIDADES CAMPESINAS DE ASENTAMIENTOS RURALES EN EL TERRITÓRIO CANTUQUIRIGUAÇU, ESTADO DE PARANÁ, BRASIL
}

\section{RESUMEN}

En Brasil, los asentamientos rurales son la manifestación principal de la reforma agraria. Ellos están desplegados por los gobiernos federal, estatal o municipal y cumplir con los más variados tipos de campesinos y territorios. Mientras que las tierras de garantía para aquellos que aún no poseen también sirven como referencia para la lucha por la tierra en manos de otros agricultores. Este artículo trata de algunos elementos de la variedad de estas políticas se destacan a la territorialidad de los tipos de asentamientos en el Territorio Cantuquiriguaçu, ubicado en el estado de Paraná. Se estudiaron tres tipos de asentamientos: el Projeto de Colonização (PC), el Projeto de Assentamento Federal (PA) y el Projeto de Reassentamento de Atingidos por Barragens (PRB). Ellos se despliegan para cumplir con las exigencias de la lucha de los campesinos a mantener su forma de vida y de producción. Les mostramos cómo sentarse campesinos con identidades distintas, constituyendo diferentes territorialidades.

Palabras clave: Reforma agraria, Asentamientos rurales, Campesinos.

\section{TERRITORIALITIES PEASANT IN THE TYPES OF RURAL SETTLEMENTS OF THE TERRITÓRIO CANTUQUIRIGUAÇU, PARANÁ STATE, BRAZIL}

\begin{abstract}
In Brazil the rural settlements are the main manifestation of the agrarian reform. They are deployed by federal, state or municipal and meet the most varied types of peasants and territories. They ensure that the land does not have to and serve as reference for wanting to conquer it. This article deals with some elements of the variety of these policies stand out to the territoriality of the types of settlements of the Território Cantuquiriguaçu, located in the state of Paraná. We studied three types of settlements: the Projeto de Colonização (PC), the Projeto de Assentamento Federal (PA) and the Projeto de Reassentamento de Atingidos por Barragens (PRB). They are deployed to meet the demands of the peasants struggle to maintain their way of life and production. We show them how to sit peasants with distinct identities, constituting different territorialities.
\end{abstract}

Keywords: Land Reform, Rural Settlements, Peasants.

\section{INTRODUÇÃO}

No Brasil, a principal manifestação da reforma agrária se dá através da implantação dos assentamentos rurais. De acordo com Fernandes (1999) eles são triunfos e trunfos da luta pela terra. São trunfos por representarem a resistência frente ao capital, a conquista do território e a possibilidade de garantir a reprodução do seu modo de vida e trabalho. São trunfos por que servem como referência para que outras lutas sejam realizadas. Os acampados que ainda estão em busca do acesso a terra veem nos que já a conquistaram um exemplo que os motiva a se sustentaram na luta pela terra. Os assentamentos representam, portanto, a conquista de territórios materiais (terra) e de territórios imateriais (sonhos, ideologias etc.) (Fernandes, 
2007). Eles se caracterizam como uma ação fundiária, por meio da qual é garantida terra a quem não possui e fomentam a luta daqueles que estão acampados e ainda não a conquistaram.

A realidade dessas políticas, no Brasil, tem adquirido um caráter diversificado no que tange aos camponeses assentados e aos territórios destinados a sua efetivação. Os assentamentos rurais não têm sido implantados apenas por meio da desapropriação tendo por beneficiários os camponeses que ainda não possuem terra. Eles também têm sido implantados através de processos como o reconhecimento, a regularização fundiária, a compra, a doação e outros. Eles não têm sido implantados apenas no campo, obedecendo ao modelo agropastoril, sendo implantados também nas florestas, muitas vezes possuindo territorialidades agroextrativistas.

Compreender essa realidade tem sido um desafio ao qual temos nos proposto nas atividades realizadas no Núcleo de Estudos, Pesquisas e Projetos de Reforma Agrária (NERA) da Faculdade de Ciências e Tecnologia da Unesp, campus de Presidente Prudente. Tomando por referência o Banco de Dados da Luta pela Terra (Dataluta) temos discutido os limites e possibilidades da reforma agrária no Brasil, considerando a correlação de forças entre os camponeses, o capital e o Estado.

Nesse trabalho apresentamos análises para contribuirmos com essas discussões. Os resultados aqui expressos compõem a dissertação de mestrado "Um estudo da diversidade e atualidade da reforma agrária: análise dos tipos de assentamentos do Território Cantuquiriguaçu, estado do Paraná", que foi defendida em agosto de 2011. Nessa pesquisa nos foi possível conhecer assentamentos de três tipos: o Projeto de Colonização (PC), o Projeto de Assentamento Federal (PA) e o Projeto de Reassentamento de Atingidos por Barragens (PRB). Constatamos que as diferentes demandas manifestadas pelos camponeses na busca pelo acesso a terra constituem as territorialidades que formam os assentamentos.

Dividimos o artigo em quatro partes. Na primeira destacamos os tipos de assentamentos que existem no Brasil, frisando algumas das características que lhes dão origem. Nas segunda, terceira e quarta, apresentamos, respectivamente, elementos da territorialidade que os camponeses desenvolvem nos assentamentos dos tipos PC, PA e PRB no Território Cantuquiriguaçu.

\section{OS TIPOS DE ASSENTAMENTOS NO BRASIL}

Conforme observamos no quadro 1, existem 20 tipos de assentamentos rurais no Brasil. Os tipos são diferentes devido a identidade dos camponeses e suas demandas. Dentre esses assentamentos alguns estão fora de vigência, ou seja, não são mais implantados por órgãos federais, estaduais ou municipais. Esse é caso dos tipos que são parte de programas de colonização implantados pelo Regime Militar como o PAC, o PAD, o PAR, o PC e o PIC. Outros possuem características agroflorestais como o PAE, o PAF, o FLONA, o RESEX, o RDS, o FLOE e o PEAEX. Em alguns desses as atividades desenvolvidas possuem caráter extrativista, demandando por isso, maiores porções de terra. Além desses, destacam-se os assentamentos que são construídos como forma de reconhecimento do territórios de

\footnotetext{
${ }^{1}$ Elaborada com o auxílio de recursos financeiros do Conselho Nacional de Desenvolvimento Científico e Tecnológico (CNPq).
} 
comunidades tradicionais, como é o caso dos AQ's (voltados para quilombolas) e os PFP's (voltados para fundos de pasto, os quais vivem na região do Médio São Francisco, estado da Bahia). Também constam assentamentos que são implantados como forma de compensar famílias que foram prejudicadas pela construção de grandes obras de infraestrutura, especialmente as barragens, como é o caso dos PRB's.

Quadro 1. Brasil. Tipologia de assentamentos de Reforma Agrária, 1961-2010

\begin{tabular}{|c|c|c|c|}
\hline & SIGLA & TIPOS DE PROJETOS DE ASSENTAMENTO & ÓRGÃO RESPONSÁVEL \\
\hline 1 & PA & Projeto de Assentamento Federal & $\begin{array}{c}\text { INCRA/INSTITUTOS DE } \\
\text { TERRAS ESTADUAIS }\end{array}$ \\
\hline 2 & PAE & Projeto de Assentamentos Agroextrativista & $\begin{array}{c}\text { INCRA/INSTITUTOS DE } \\
\text { TERRAS ESTADUAIS }\end{array}$ \\
\hline 3 & AQ & Assentamento Quilombola & $\begin{array}{c}\text { INCRA/INSTITUTOS DE } \\
\text { TERRAS ESTADUAIS }\end{array}$ \\
\hline 4 & PRB & Projeto de Reassentamento de atingidos por & $\begin{array}{c}\text { INCRA/GOVERNOS } \\
\text { ESTADUAIS }\end{array}$ \\
\hline 5 & PAF & Projeto de Assentamento Florestal & INCRA \\
\hline 6 & PDS & Projeto de Desenvolvimento Sustentável & INCRA \\
\hline 7 & PAC & Projeto de Assentamento Conjunto & INCRA \\
\hline 8 & PAD & Projeto de Assentamento Dirigido & INCRA \\
\hline 9 & PAR & Projeto de Assentamento Rápido & INCRA \\
\hline 10 & PC & Projeto de Colonização Oficial & INCRA \\
\hline 11 & PIC & Projeto Integrado de Colonização & CDA \\
\hline 12 & PFP & Projeto Fundo de Pasto & ESTADUAIS \\
\hline 13 & PE & Projeto de Assentamento Estadual & INSTITUTOS DE TERRAS \\
\hline 14 & PAM & Projeto de Assentamento Municipal & GOVERNO MUNICIPAL \\
\hline 15 & PCA & Projeto de Assentamento Casulo & GOVERNO MUNICIPAL \\
\hline 16 & FLONA & Florestas Nacionais & ICMbio* \\
\hline 17 & RESEX & Reserva Extrativista & ICMbio* \\
\hline 18 & RDS & Reserva de Desenvolvimento Sustentável & ICMbio* \\
\hline 19 & FLOE & Floresta Estadual & CEUC/SDS*** \\
\hline 20 & PEAEX & Projeto de Assentamento Agroextrativista & ITERPA*** \\
\hline Fonte: Dataluta, 2011. Organização própria. & \\
\hline
\end{tabular}

*Instituto Chico Mendes de Conservação da Biodiversidade

**Centro Estadual de Unidades de Conservação/Secretaria de Estado do Meio Ambiente e Desenvolvimento Sustentável (Amazonas)

***Instituto de Terras do Pará

Essa diversidade indica que a reforma agrária brasileira é caracterizada por uma amplitude de ações, que vão além dos casos de desapropriação em benefício dos camponeses que ainda não estão na terra. Ela também tem beneficiado os camponeses que estão na terra, todavia, sem possuir o título de propriedade. Essa tendência tem se ampliado após a elaboração do II Plano Nacional de Reforma Agrária (II PNRA) pelo Governo Federal Brasileiro, no qual são prevista ações diversificadas para a implantação dos assentamentos rurais.

Como forma de ampliar nossa leitura sobre esse processo visitamos assentamentos do Território Cantuquiriguaçu. Ele é formado por um conjunto de municípios pertencentes as mesorregiões Oeste Paranaense e Centro-Sul Paranaense e possui significativo histórico de luta pela terra por parte dos movimentos socioterritoriais. No Território Cantuquiriguaçu existem três tipos de assentamentos: o PC, o PA e o PRB (Prancha 1). 


\section{Prancha 1. Território cantuquiriguaçu. Tipos de assentamentos rurais, 1984-2009}
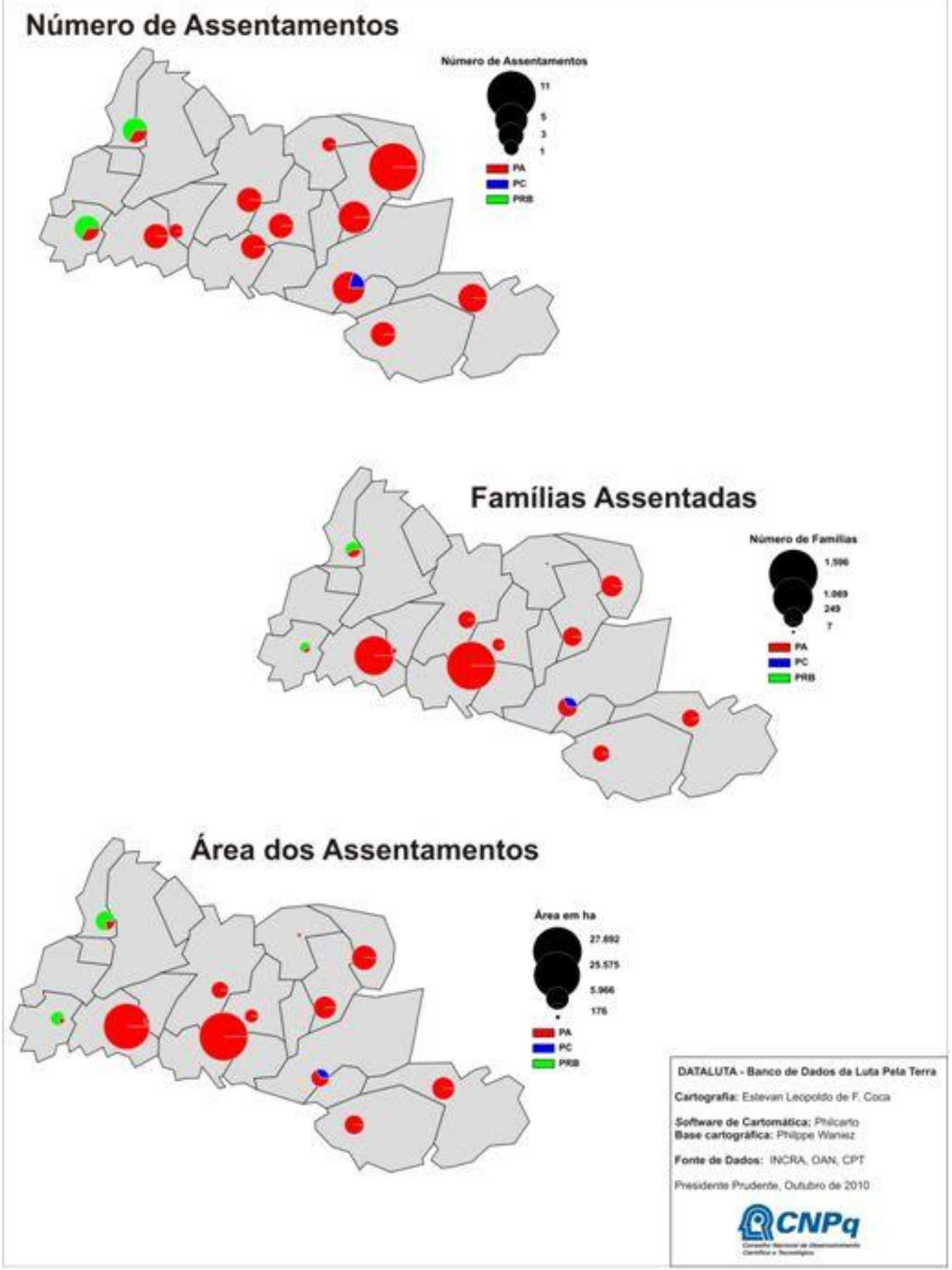

Fonte: Organização própria.

Nas visitas, entrevistamos lideranças dos assentados e buscamos conhecer as territorialidades que são desenvolvidas nesses projetos, como os camponeses se organizam para poder permanecer na terra e garantir a reprodução do seu modo de vida e trabalho. Á seguir, apresentamos alguns resultados dessas análises. 


\section{O TIPO PC}

No Território Cantuquiriguaçu temos 1 assentamentos do tipo PC, que é o Ilhéus, o qual localiza-se no município de Candói. Ele foi implantado no ano de 1984, sendo composto por famílias que viviam nas margens do rio Paraná, no município de Guaíra (divisa entre os estados do Paraná e Mato Grosso do Sul) e que foram expropriadas devido à construção da Usina Hidrelétrica de Itaipu. O depoimento de Antônio Tavares Pereira, uma das lideranças dos assentados, demonstra como se deu tal processo.

[...] a "espoliação" dos ilhéus do rio Paraná deu-se desde 79, quando os ilhéus habitavam as ilhas, plantavam arroz, feijão, milho, mandioca; diversificado. Ali nunca se houve plantio de pacotes químicos, nem se ouviu falar em veneno, essas coisas químicas. Então, o povo plantava de maneira sustentável, vivia em harmonia com a natureza, até a criação da hidrelétrica de Itaipu em 1979. Foi o fechamento da hidrelétrica... ali provocou grande cheia no rio Paraná, impossibilitando os ilhéus de fica dentro das ilhas e então os ilhéus tiveram que sair para as margens do rio, fica acampado debaixo de lona preta e ficamos...ficamos dois anos debaixo de lona preta com a esperança de que as águas baixassem pra gente volta pras ilhas, mais isso foi impossível porque ela deu uma baixada e em 82 deu uma cheia e ela parou no limite tampando as ilhas e aí então a gente perdeu a esperança de que as água fosse baixa, cerca as terra pra que a gente tivesse possibilidade de volta (Antônio Tavares Pereira - Liderança do PC Ilhéus - 15/03/2010).

O relato demonstra como a construção da Usina Hidrelétrica de Itaipu desestabilizou o modo de vida e produção dos ilhéus. $\mathrm{O}$ uso que eles faziam de seus territórios, não objetivava o lucro, mas a garantia de sua reprodução social. Eles se orgulhavam de não fazer uso de implementos químicos para aumentar a produção, já que prezavam pela convivência harmônica com o meio ambiente. Com a construção da Usina, grande parte das famílias expulsas de suas terras teve que recorrer aos acampamentos organizados nas margens do rio até que o assentamento fosse implantado.

O nome Ilhéus é dado pelo fato de os camponeses assentados terem forte relação com a água. Como anteriormente viviam próximos ao rio, desenvolveram um modo de ser e de produzir que traz essa característica explicita em sua identidade. Da mesma forma como desenvolviam produções agrícolas também se dedicavam a pesca, a qual é "[...] uma atividade extrativa, cujo ambiente de trabalho não é passível de apropriação privada e de um controle que permita imprimir uma racionalidade capitalista no conjunto de sua exploração" (Schiavoni, 1996, p. 28). Por esses fatores, os camponeses do Ilhéus preferem ser reconhecidos como "ilhéus" e não como "assentados".

Apesar de terem sido assentados no Paraná, o seu estado de origem, os ilhéus encontraram consideráveis dificuldades para se adaptar a nova realidade, como é demonstrado no depoimento abaixo: 
[...] nós sofremos muito com isso, porque o pessoal nosso, eles têm um modo de fala, uma língua e um comportamento. Nós tinha nossa cultura, nossas festas cultural e muitas vezes no lugar que nós foi colocado, nessa região é diferente a cultura do povo e nós muitas vez somos ignorado pelo próprio povo, pois nós trazia nosso modo de sê, de viver e que eles não... Muitas vezes é errado na região que colocaram a gente. Eles, achando errado, por falta de entendimento, acusava a gente de sê pessoas ruim. Então, nós sofremos o preconceito na região onde nos pôs, desde o clima... A região noroeste do estado do Paraná pra quem conhece a região sabe que o clima é um clima mais quente, é um clima mais... A temperatura mais elevada, de 25 a 30, vai até 40, 46,50 graus. Na época, ela baseava até 43 . Nós viemos pra uma região que vai 10 abaixo de 0 , isso dá geada que branquia tudo, então, mais o desequilíbrio, as doença, as ipidemia acabo com a saúde do nosso povo, nós tivemos que aprende os costumes da região sul ou centro do Paraná em conflito, e aprendendo a desdobra a língua pra não pode entra em conflito com o pessoal da própria região. Tivemos que se adapta, muito do nosso pessoal não consegui ficar [...] (Antônio Tavares Pereira Liderança do PC Ilhéus - 15/03/2010).

Demonstra-se que as dificuldades de adaptação ao território ofertado pelo Incra causaram grande impacto na vida das famílias reassentadas no Projeto de Colonização. Na nova região, eles não observaram apenas diferenças físicas, como a temperatura e o relevo, por exemplo; mas também culturais (fala, costumes e outros). Por estes motivos, grande parte dos ilhéus que foram assentados no centro-sul paranaense desistiu de seus lotes. Entretanto, os entrevistados frisam que no PC Ilhéus os índices de desistência foram menores se comparados aos demais assentamentos para os quais os ilhéus foram trazidos. Os motivos, segundo eles, foram as vantagens que este assentamento apresentava em relação aos demais, como a terra fértil e proximidade dos corpos d água. Assim, viam a possibilidade de desenvolver a agricultura de subsistência aliada à pesca, como ocorria nas ilhas do rio Paraná.

O local onde foi implantado o PC Ilhéus é marginal ao rio Cavernoso e ao Lago da Usina Hidrelétrica de Salto Santiago (Figura 1), sendo que a maioria dos 80 lotes fica próxima a algum desses corpos d água.

Fica claro que para os assentados ser ilhéu é essencial para manter o controle do território. Eles devem estar próximos da água não apenas para desenvolver seu modo de produção, mas também como algo que é constituinte do seu modo de vida. A terra e a água servem para que eles mantenham sua identidade, sua cultura, suas práticas, não sendo usada como fonte de lucro.

A média de cada lote é 14 ha, o que é considerado pequeno pelos ilhéus, já que no assentamento existe um relevo acidentado (Fotografia 1). Isso torna praticamente inviável a permanência de filhos e agregados no assentamento quando esses atingem a idade adulta. 


\section{Figura 1. Localização do projeto de colonização Ilhéus}

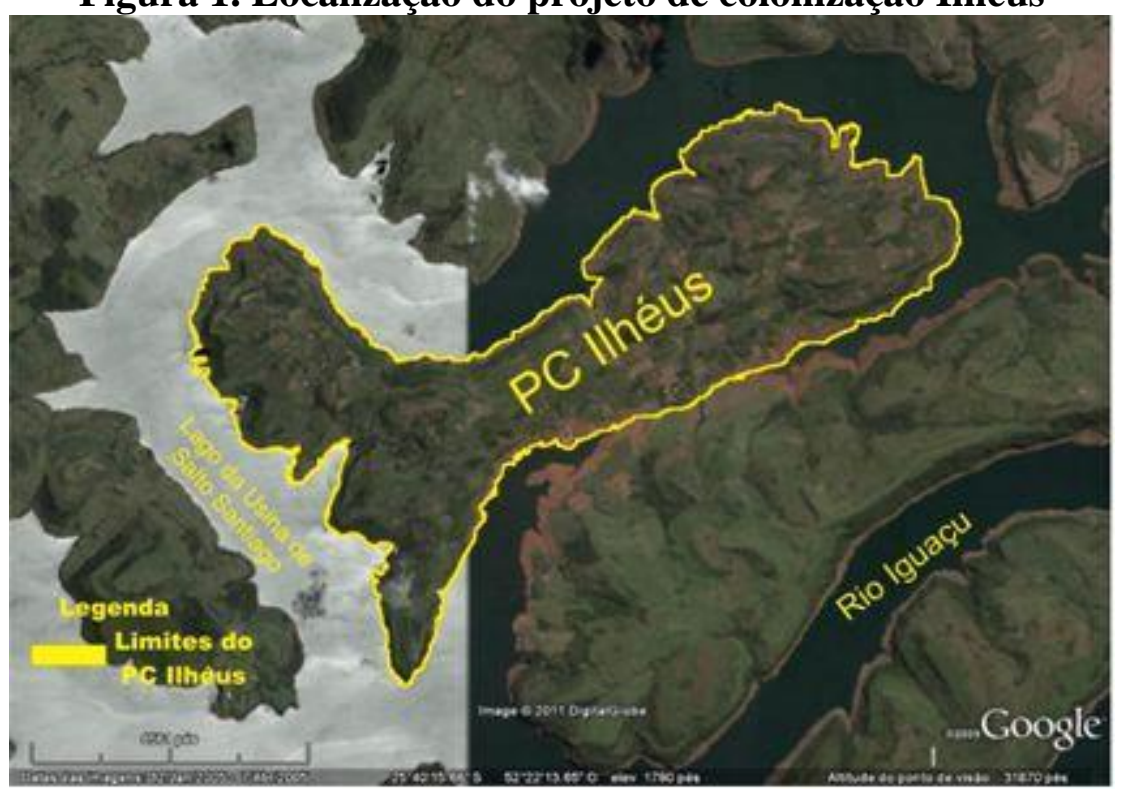

Fonte: Google Earth, 2010.

\section{Fotografia 1. Relevo do assentamento Ilhéus}

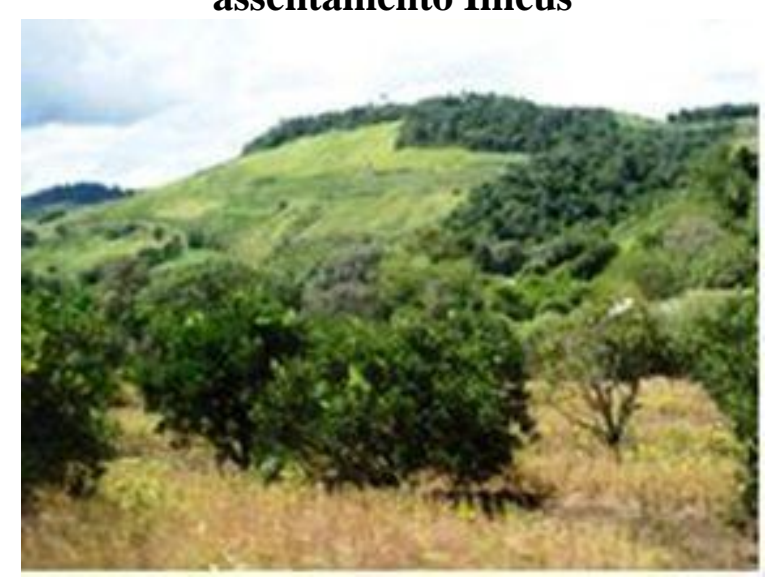

Autor: Estevan Coca. Data: 15/03/2010.

A posse dos lotes se dá através de títulos de propriedade. Na criação do assentamento, a intenção do Incra era que ela ocorresse através de concessões de uso, todavia, os assentados alegaram que já possuíam terra e que não seria justo não terem o título de propriedade dos lotes, prescrição que foi observada. Em seu relato, Pedro Tavares demonstra a importância de ter o título de propriedade:

[...] essa foi uma briga de início, eles queriam passar isso aqui em concessão de uso, pra gente não ter título. Não podia ficar pro resto da vida, mas foi uma briga do início, porque nós queria nossa terra trocada por outra terra e que tivesse um título definitivo (Pedro Tavares Pereira - Liderança do PC Ilhéus 15/03/2010). 
O depoimento demonstra que ter o título de propriedade é ter a certeza de poder ficar na terra para o resto da vida, se assim for o desejo da família assentada. Os ilhéus julgavam injusto não terem o título da terra por terem sido expulsos das ilhas em que viviam de maneira violenta, sem terem a opção de decidirem pelo seu próprio futuro.

Com a concessão de uso, os assentados utilizariam um território pertencente ao Estado, desenvolveriam sua vida e suas práticas produtivas naquelas terras, mas não teriam a certeza de que elas lhes pertenciam. Com o título de propriedade o território pertence a eles, garantindo sua reprodução social. Isso demonstra que nos projetos de colonização essa questão não é estática, ter o título de propriedade ou não é uma questão a ser negociada entre o Incra e os agricultores assentados. Apesar de não ser demonstrado nos depoimentos, dado ao cuidado das lideranças entrevistadas, observamos que em alguns casos o título é buscado como uma tentativa de poder vender o lote por parte dos assentados.

Todavia, mesmo com o título de propriedade de uma nova área concedida pelo Incra como forma de indenização pelos passivos sofridos, os ilhéus ainda estão vinculados legalmente aos territórios inundados pelo lago de Itaipu. Nos depoimentos, eles alegam com pesar, que ainda pagam o ITR das áreas que foram inundadas. Quando foram assentados, houve a promessa de que em breve seriam indenizados, fato que até hoje não ocorreu. Em setembro de 1997, na área em que as ilhas existiam foi criado o Parque Nacional de Ilha Grande, ocupando mais de 78 mil ha e que hoje é administrado pelo ICMbio. Parte dos agricultores que habitavam as ilhas se uniram e formaram a Associação dos Ilhéus Atingidos pelo Parque Nacional de Ilha Grande (APIG), com sede em Guaíra e que há mais de uma década tem trabalhado para a conquista da indenização por parte dos ilhéus, fato que ainda não ocorreu devido à grande exigência de documentos que tem sido feita pelos órgãos federais.

A principal produção desenvolvida no assentamento é a de laranja. Para isso colaborou uma parceria como os governos estadual e municipal quando da implantação do assentamento. Antonio Tavares demonstra uma opinião crítica sobre esse fato:

[...] o modo da gente planta, viver lá dentro das ilha, era um sistema que eles falam de diversificação, hoje eles falam isso. Pra nós aquilo lá, nós falava assim, é um plantio tudo misturado, como se diz a moda antiga o baião de dois. Lá, nós plantava arroz, feijão, milho, tudo no mesmo terreno, tudo misturado. Plantava o milho nos carreirão, plantava o feijão no meio, aí o feijão tava "coisano", nós plantava arroz no lugar do feijão e as verduras, a horta era jogada pro meio da roça, então, nunca se via fala, que a pessoa fazia sua horta de alimentos na beira da casa, no seu quintal, era sempre feito pela roça, jogado a semente. A terra nunca se viu fala de ponhar adubo...nada. A terra tem uma riqueza tão grande, porque os ciclo das água, quando repontava, apodrecia o mato, que tinha seco nas capina no meio da roça e virava adubo e aquilo enriquecia o solo. Então, a gente nunca preciso de compra adubo, nem adubar, nem fazer horta separado, jogava a semente e lá produzia à vontade. Então, a gente não tinha preocupação com horta, nem com nada, era tudo junto e sempre tinha alimento farto e sabiam 
que nunca ninguém uso veneno, nem tratamento pra folha, nada, porque a força da planta não entrava doença, nada e o peixe, o pessoal quando tava pronto, que pegava aquela vara baixa do baxil, onde era os franco de arroz, aquilo ali era uma reprodução de peixe tão grande, que era como se compara uma bixera de peixinho comendo as planta, os arroz. Então, nesse período das cheia, nós...nosso serviço era pesca, e pescava para o sustento, muitos do nosso pessoal vendia o peixe, muitos compraram o barco, carroça, cavalo, arado, essas coisa pra poder facilita a manutenção nas ilha, transporte, essas coisa. Com o dinheiro do peixe, então, só tinha riqueza dentro desse ciclo das águas e quando as água baixavam as terra ficava fértil e nós continuava plantando, sem ir lá. Não se existia veneno e nem semente tratada, era tudo semente criola, que a gente produzia a própria semente, criava os animais.... A única forma que nós melhorava a genética do nosso criame era trocando com os vizinho, por exemplo, o porco a gente trocava cachacinho com o vizinho lá longe, aí os porco tudo bonito, grande, o bezerro... Então, assim, a gente fazia continua as espécies fazeno o sistema de troca de plantas e de animais, questão de sementes e a comunidade vivia bem, sem endividamento, sem nada. Hoje nós estamos tudo "lascado", porque a assistência técnica que nós recebemos no assentamento da ilha do Cavernoso, depois que viemos pro assentamento, ela nos orientou a pranta uma planta só, alegando que nós ia produzir mais Uma planta ira rouba o alimento da outra. Então, isso ia rende na produção, a produção ia sê melhor, nós ia consegui mais renda. Então, comecemos a planta arroz, só arroz; milho, só milho; feijão, só feijão; e assim até hoje os ilhéus vão perdendo seu modo de vida, de cultiva a terra, de sustentabilidade e ainda, assim mesmo, hoje, com um sistema que é inchado, ela fica um poco difícil, já estamos passando veneno nas terra pra limpa as planta, pra cultiva e isso tá saindo do nosso mundo e nós temo que viver, conviver com isso, porque não tem outras condições, então é um pouco isso [...] (Antônio Tavares Pereira - Liderança do PC Ilhéus 15/03/2010).

O relato demonstra como era desenvolvida a agricultura nas ilhas habitadas pelos camponeses ilhéus anteriormente. As práticas produtivas eram diversificadas, não se tinha o interesse de produzir somente uma cultura, já que a comercialização em larga escala não era o objetivo primeiro. É interessante observar que o sistema agrícola estava relacionado com as cheias do rio Paraná, o que demonstra que os ilhéus possuíam com a água não só um vínculo afetivo, mas também produtivo. Na época das cheias a produção aumentava, possibilitando com que eles vendessem parte dela, podendo assim adquirir alguns bens materiais, entretanto, este não era o foco da agricultura por eles desenvolvida. Com a transferência para o assentamento, estes camponeses são incentivados a se dedicar a uma única produção, no caso a laranja. Os conhecimentos que eles possuíam até então são colocados em segundo plano, visando melhor inseri-los ao mercado. Aí reside o principal motivo do insucesso desta iniciativa. 
Ainda sobre as práticas produtivas, no PC Ilhéus o trabalho desenvolvido nos lotes é predominantemente familiar, o que caracteriza a produção como camponesa (Chayanov, 1974). Nas épocas de colheita, o trabalho familiar tende a não ser suficiente, nesses casos recorre-se a ajuda dos vizinhos, como forma de organização, o que é explicado por Pedro Tavares Pereira:

[...] na época da colheita tá tendo um problema muito sério, nós estamos ficando sem mão-de-obra, nossos filhos, nossos jovens, como já te falei, estão saindo para caçar seus meios... Um problema grande... Estão ficando só as pessoas adultas. Na época da colheita da laranja, do milho é difícil pessoa. Não é fácil... Tem que fazer mutirão, tem que pedi pra tá junta pra colhe as laranja, então tá nessa forma (Pedro Tavares Pereira Liderança do PC Ilhéus - 15/03/2010).

A preocupação com a existência de condições que garantam a realização do trabalho de base familiar demonstra o entendimento de que se outras relações como o assalariamento, por exemplo, passarem a ser desenvolvidas no assentamento, os assentados podem perder o controle sobre o território. A saída dos jovens exige que os membros restantes das famílias intensifiquem sua carga de trabalho. Para não recorrer a outras relações de trabalho, nos casos onde isso não é suficiente, especialmente na época da colheita, faz-se necessário requerer à ajuda de outras famílias assentadas em um sistema de ajuda mútua. É comum que quando termina o trabalho da colheita a família beneficiada com o mutirão realize um festejo em comemoração e como forma de retribuir o auxílio recebido dos demais.

No que se refere aos movimentos socioterritoriais, no PC Ilhéus nenhum deles tem atuado na organização dos camponeses. Constata-se que o Movimento dos Trabalhadores Rurais Semterra (MST) exerceu a função de auxiliar os camponeses na luta pela permanência na terra, contudo, o assassinato de Antônio Tavares, uma das lideranças dos assentados, em 2 de maio de 2002 gerou uma espécie de medo coletivo, fazendo com que o movimento perdesse poder de ação gradualmente até deixar de atuar nesse território.

Essas condições de ausência de vínculo com as demais lutas pela terra, através da atuação dos movimentos socioterritoriais nos demonstram que as conclusões a que chegaram Tavares dos Santos (1985) e Ianni (1979) também se aplicam ao assentamento estudado: os projetos de colonização freiam a mobilização social dos agricultores e desestabilizam a luta pela terra na região de origem dos colonos.

\section{O TIPO PA}

O PA, o tipo de assentamento mais implantado no Brasil, também é o que possui maior número no Território Cantuquiriguaçu, representando $87 \%$ dos assentamentos, $95 \%$ das famílias assentadas e $91 \%$ da área destinada aos assentamentos. Em termos nacionais, a origem desse assentamento está atrelada as ocupações de terra. Prova disso é que $78 \%$ dos PA's implantados no Brasil entre 1961 e 2010 tiveram como política de obtenção a desapropriação. 
Nos trabalhos de campo visitamos 3 assentamentos desse tipo: Ireno Alves dos Santos e Marcos Freire, no município de Rio Bonito do Iguaçu e Celso Furtado, no município de Quedas do Iguaçu. Esses foram implantados em uma área que anteriormente compunha o maior latifúndio do sul do Brasil, pertencente a empresa Giacomett Marodin, o qual possuía 83 mil ha e se estendia pelo território de 4 municípios, tendo como principal atividade produtiva a exploração madeireira.

A territorialidade camponesa encontrada nos PA's analisados está atrelada ao período de luta pela terra e mais especificamente a atuação do MST na organização das famílias. Já no ano de 1980 os camponeses haviam tentado ocupar as terras desse latifúndio, todavia, imediatamente houve a reação dos latifundiários, que contavam com o apoio de jagunços e da Polícia Militar paranaense. Sobre esse episódio, escreve Fernandes (1999, p. 55):

Foi uma operação de terror: rajadas de metralhadoras por sobre a cabeça das pessoas deitadas; amarraram outras em árvores e torturaram. Foram despejados, mas ficou a marca, tanto nos corpos de muitos trabalhadores como em suas mentes. Aquele latifúndio haveria de ser conquistado. Do decreto de desapropriação não se falou mais. O Incra não se manifestou. Àquela terra tinha um destino: a conquista pelos camponeses. Era uma questão de tempo, de se fazer a história.

Mesmo não tendo conseguido alcançar o objetivo traçado nessa primeira tentativa, os camponeses do MST não desistiram de conquistar essa área. O relato de Danilo Ferreira, uma das lideranças MST, que vive no assentamento Ireno Alves dos Santos, demonstra como este território era visto pelos sem-terra:

[...] essa área... desde que surgiu o MST no Paraná como organização, começou a se discutir; até porque (era) um dos principais, ou o principal latifúndio do Paraná e a intenção das lideranças era ocupar isso porque na verdade nós estaríamos fazendo uma disputa nos extremos com os fazendeiro e aí até quando ocupavam outras áreas os caras diziam: "porque vocês não ocupam a Giacomet". Eles desafiavam no debate e por várias vezes foram feitos acampamentos aqui na região, pensando em reunir famílias pra ocupar essa área, mais nunca conseguimos chegar a um número bom de famílias para que se desse uma conjuntura favorável para se poder bancar uma ocupação desse nível, então, ia indo pra áreas vizinhas, tem aqui o assentamento Chagú, vários assentamentos em Cantagalo, Laranjeiras, poderia citar aí vários, mais eram famílias sendo organizadas tentando vim pra cá. Aí não dava o número suficiente você tinha que ir pra outro lado [...] (Danilo Almeida Liderança do PA Ireno Alves dos Santos - 16/03/2010). 
A fala demonstra que enfrentar este latifúndio era, acima de tudo, uma disputa por território imaterial. Era uma questão de honra para os sem-terra ferir aquele que era, na região onde viviam, o maior expoente da relação produtiva que lhes causara a miséria.

Passados 16 anos da primeira ocupação realizada no latifúndio, em 1996 seria gerada uma conjuntura que possibilitaria novamente a ação dos sem-terra neste território. Em março deste ano, nas margens da BR-158, nos municípios de Saudade do Iguaçu e Laranjeiras do Sul são formados dois grandes acampamentos onde seria criado o espaço político que posteriormente possibilitaria a ocupação. No mês de abril, as cerca de 3 mil famílias que participavam destes acampamentos, totalizando quase 15 mil pessoas, saem em marcha rumo ao latifúndio, vindo, finalmente a ocupá-lo.

Ocorria assim, a maior ocupação de terras já registrada no sul do Brasil. O momento da entrada dos sem-terra, abrindo a porteira da fazenda ficou imortalizado nas fotos de Sebastião Salgado que ganharam notoriedade mundial.

A ocupação representava o enfrentamento do sem-terra contra o latifúndio. As famílias pertencentes ao MST manifestavam sua resistência perante o processo desigual e contraditório de desenvolvimento do capitalismo. Buscavam sua recriação. Com a ocupação é criado um novo espaço de luta pela terra, que é o acampamento (Fernandes, 1999). As famílias que participaram da ocupação da fazenda da Giacomett Marodin passaram a morar no acampamento "Buraco", que ficava instalado nas margens da BR-158, junto ao rio Xagú e próximo à sede da fazenda ocupada. Neste novo espaço de luta e resistência, os sem-terra viviam em situação de extrema miséria, todavia, adquirindo grande conscientização política, entendendo a importância de lutar coletivamente. Era uma pequena área, onde viviam as quase 15 mil pessoas.

Já no acampamento começava a ser gestada a territorialidade dos assentamentos em estudo, pelo fato de o MST lá trabalhar com a organicidade de seus membros, visando à tomada de decisões pelo coletivo e evitando o individualismo. Foram formados grupos de 20 a 30 famílias, dentre os quais eram eleitos coordenador geral, de infraestrutura, saúde, alimentação, acompanhamento e negociação. Em cada grupo uma pessoa era incumbida de cuidar dos assuntos de educação e outra da catequese. Na reunião geral era tomado extremo cuidado para que não entrassem "penetras", ou seja, pessoas que vinham em busca de obter informações que pudessem prejudicar as ações dos sem-terra (Hammel, Silva e Andreatta, 2007).

No dia 16 de janeiro de 1997 os camponeses Vanderlei Neves e José Alves dos Santos, que estavam acampados à espera da desapropriação da área foram assassinatos brutalmente. Esse fato ganhou considerável repercussão midiática, forçando o Governo Federal a desapropriar 16.852 ha que deram origem ao Ireno Alves dos Santos, apenas um dia depois. Nele foram assentadas 900 famílias. As 606 excedentes foram assentadas no Marcos Freire em novembro de 1998 em uma área de 10.095 ha. O Celso Furtado surgiu como consequência de outras lutas travadas tendo como foco os hectares restantes do latifúndio, sendo implantado por arrecadação no ano de 2004, em uma área de 23.733 ha e com 973 lotes.

O aprendizado trazido do período de luta para entrar na terra é de extrema influência na territorialidade que os camponeses desenvolvem nesses três assentamentos. A importância de práticas coletivas, como meio de fortalecimento da luta pela terra e para nela permanecer demonstra-se nos assentamentos. O Plano de Consolidação do Assentamento Ireno Alves dos 
Santos (2004, p. 47) demonstra que a organização em grupos de famílias, utilizada ainda no acampamento é aplicada também no assentamento:

A população do assentamento Ireno Alves está distribuída nos lotes agrícolas. O conjunto de vários lotes próximos forma o Grupo. O Grupo é a organização primária do assentamento, tendo sua origem ainda no "acampamento", onde cada um deles recebeu um número que se conserva até hoje. No assentamento existem, distribuídos aleatoriamente, 41 Grupos, com uma média de 23 famílias por Grupo. O conjunto de vários Grupos situados numa determinada área forma a Comunidade que, em número de 15, estão espalhadas por todo o assentamento, sendo que a distância entre elas varia de 2 até $20 \mathrm{~km}$.

Os grupos são formações elaboradas quando os camponeses ainda estavam acampados, sendo que em muitos casos, motivaram fortes laços de amizade. $\mathrm{O}$ funcionamento do grupo se dá "sem regras escritas, sem diretoria, sem conselho fiscal, sem eleição. Ele tem um coordenador e os integrantes" (INCRA, 2004, p. 48). As comunidades são formadas pela proximidade dos lotes. Esses grupos são organizados em comunidades, sendo que essas são 15 no total. Na figura 03 apresentamos a comunidade Arapongas. Também no PA Marcos Freire a organização em grupos e comunidades é aplicada. No Celso Furtado são formados grupos de cinco famílias nomeados como núcleo de base e esses juntos formam uma brigada.

Fotografia 2. Comunidade

Arapongas. PA Ireno Alves

dos Santos

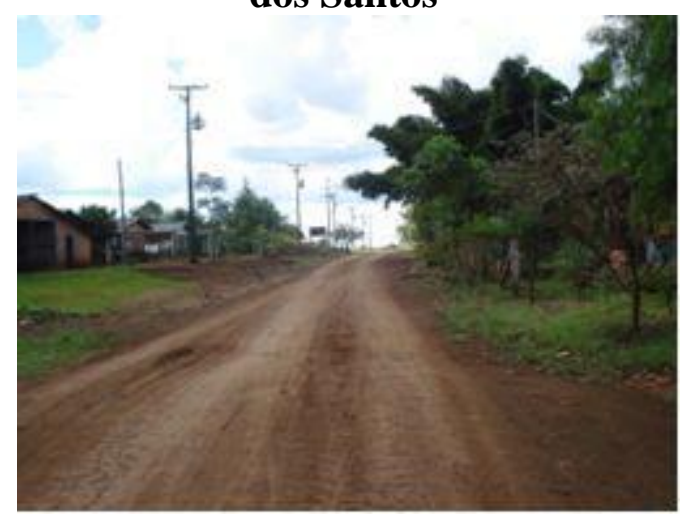

Autor: Estevan Coca. Data: 16/03/2010.

É importante salientar, que o estímulo a nucleação das famílias e a organização dos lotes em comunidades é uma prática incentivada pelo MST em nível nacional, como forma de possibilitar maior socialização e inibir as tomadas de decisão individuais (Goldfarb, 2007).

No PA's os principais produtos gerados nos lotes são o feijão, o milho a soja e principalmente o leite. No Celso Furtado existe uma proposta da Emater que visa garantir o leite como principal fonte de renda das famílias. Observa-se, que além da influência do MST na 
definição da territorialidade econômica destes assentamentos, também se destaca a do Estado, representado pelas agências de assistência técnica. Essas agências influenciam nas produções dos lotes, sendo que em muitos casos, o que era proposto pelas famílias nem sequer começa a ser desenvolvido, prevalecendo as propostas dos técnicos.

A territorialidade camponesa na dimensão econômica dos territórios destes assentamentos pode ser observada no processo e no produto das relações que os efetivam. O processo caracteriza-se pelo trabalho de base familiar, que é predominante nestes assentamentos, como mostram os PCA's do Ireno Alves dos Santos e do Marcos Freire e o PDA do Celso Furtado. Em épocas de colheita, quando o trabalho familiar não é suficiente, geralmente recorre-se ao trabalho de diaristas, que não possuem vínculo formal de trabalho. Contudo, conforme observamos nas entrevistas de Marcelites $(2010)^{2}$ e Almeida (2010) ${ }^{3}$ não se têm conhecimento de casos de assalariamento nos lotes. É comum nas famílias a existência de pessoas que trabalham fora do assentamento, como meio de completar a renda. Dentre os trabalhos desenvolvidos, duas vertentes são as mais comuns: o comércio das cidades próximas e o funcionalismo público.

O produto da territorialidade é observado pela oferta de alimentos, ao contrário do que ocorre com o capital (agronegócio), que oferece comoditties. Isso ocorre porque o objetivo da produção camponesa não é comercialização. A intenção primeira do que é gerado nos lotes é o consumo familiar e o excedente é comercializado. Os entrevistados não souberam dizer a média da renda das famílias, todavia, sabe-se que em casos extremos, chega-se a ganhar mais de sete salários mínimos com a produção de leite, enquanto outras famílias não conseguem sequer um salário mínimo, dependendo dos programas sociais do Governo Federal para suprirem algumas de suas necessidades básicas.

No assentamento Celso Furtado, a oferta de uma agricultura diferente da que é gerada pelo capital é observada na produção orgânica que é realizada por um grupo de trinta e duas famílias, organizadas em uma associação. A agricultura orgânica tem por fundamento a produção de alimentos sem o uso de insumos químicos e de organismos geneticamente modificados. No PDA, já é proposto que uma parte deste território seria destinada à produção orgânica, sendo que as famílias que não desejassem trabalhar com esta produção teriam que passar por sorteio para a definição dos lotes, as que tivessem essa intenção seriam poupadas desse processo. Assim, antes de os lotes serem destinados às famílias, aqueles que se interessavam em desenvolver a agricultura nestes moldes receberam um curso promovido pela ONG WWF Brasil, de duração de seis meses.

Na visita a campo, tivemos a oportunidade de conhecer o lote de Isidoro Manoel Luiz, que já foi presidente da associação de produtores orgânicos e que hoje atua como secretário desta mesma associação. Nesta ocasião, ele nos explicou um pouco da importância deste tipo de produção por parte dos assentados:

Acho que ela pode contribuir de várias formas. Primeiro, é a questão do produto sadio, sem químico, sem veneno [...]

\footnotetext{
${ }^{2}$ Entrevista concedida por Elder Marcelites. Projeto de Assentamento Federal Celso Furtado, em Quedas do Iguaçu, em 15/03/2010.

${ }^{3}$ Entrevista concedida por Danilo Ferreira de Almeida. Projeto de Assentamento Federal Ireno Alves dos Santos, em Rio Bonito do Iguaçu, em 16/03/2010.
} 
Contribui porque além da pessoa tá comprando um produto de qualidade e nos tá ajudando, contribui com a saúde dele também. Só pra tu ter uma idéia, aqui eu não vendo meus produtos na cidade, o pessoal pega aqui [...] eu não to me esforçando pra vender meu produto lá fora, eles pegam aqui e tem a certeza, pra deixar bem claro, nós não temos selo ainda, orgânico. Mais quando o consumidor lá fora confia em você, pego seus primeiros produtos orgânicos e confia em você o selo pra ele não tem muita importância.

O relato demonstra a diferenciação que o assentado faz da agricultura orgânica da convencional. Por meio da agricultura orgânica é ofertado um alimento mais saudável, o que acaba atraindo à atenção dos consumidores. Isidoro faz questão de frisar que não precisa sair de seu lote para vender os seus produtos, as pessoas vêm buscá-los. Entretanto, ainda existe a ausência do selo que garante o produto como orgânico. Este selo é concedido por entidades que fiscalizam as propriedades que se dedicam a este tipo de produção, como forma de garantir que nelas os procedimentos necessários para um produto orgânico estão sendo tomados. Mesmo com a dificuldade para certificação o assentado se mostra satisfeito com os resultados conseguidos até agora. Aqueles que optam pela produção orgânica têm a satisfação de oferecer uma agricultura mais saudável do que a ofertada pelo capital, como está expresso na placa de entrada de um dos lotes onde se desenvolvem tais práticas (Fotografia 3).

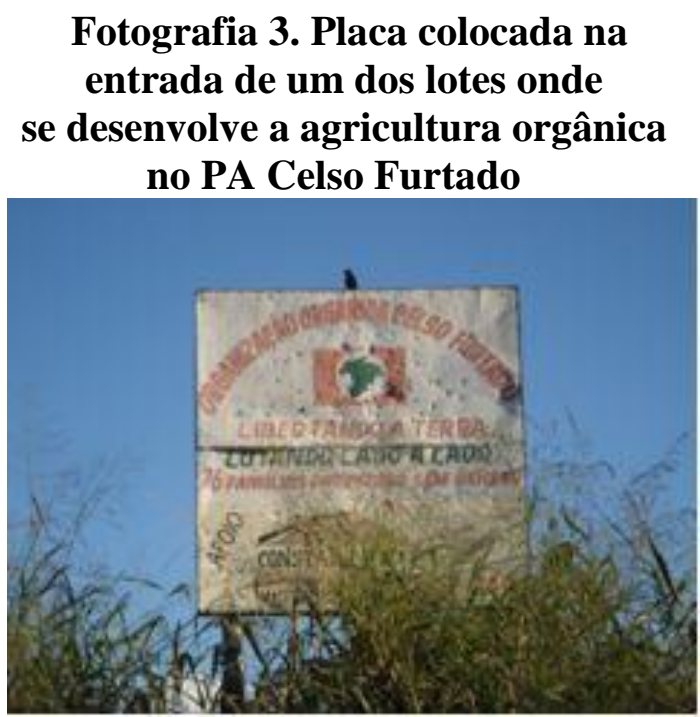

Autor: Estevan Coca. Data: 16/03/2010.

A frase contida na figura demonstra a idéia de libertar a terra através da agricultura orgânica. Poderíamos indagar: Libertar de quem? A resposta é objetiva: do capital e seus métodos de exploração que agridem o meio-ambiente, além de explorar o trabalho de grande parte daqueles que vivem no campo. Dentre os produtos orgânicos gerados nos lotes existe uma grande diversidade, entretanto, destacam-se a produção de mandioca, batata, abóboramoranga e milho. Constata-se que apesar de ainda estar em fase de estruturação, a produção 
orgânica traz alguns dos objetivos da territorialidade que o MST visa instaurar na dimensão econômica do território do assentamento.

Entendendo a territorialidade também como estratégia para permanência no território, constatamos que a opção por essa prática produtiva vai muito além da tentativa de criar meios diversificados para a obtenção de renda das famílias. Ela representa um posicionamento crítico frente ao modelo produtivo vigente, gerado pelo capitalismo.

A influência do MST faz com que, em grande parte das famílias assentadas, existe um grande grau de politização. $\mathrm{O}$ aprendizado trazido da luta pela terra os leva a se posicionarem de maneira crítica frente às políticas que têm sido efetivadas no campo.

Como fator de destaque desta politização, destacamos a luta por um processo educacional que privilegie os valores do homem do campo. Para o MST, o posicionamento crítico, enquanto classe social, por parte dos assentados ocorrerá na medida em que a eles for ofertada uma educação que não despreza a condição camponesa de vida e produção. Considera-se que o atual modelo educacional faz com que as crianças e os jovens não sintam interesse em permanecer no campo, já que se valoriza o meio urbano, tratando-o como moderno e desvaloriza-se o meio rural, tratando-o como sinônimo de atraso (MST, 2009). A educação oferecida aos assentados deve ser entendida como um processo contínuo, onde o educando deve se experimentar no mundo para poder conhecer-se. Além disso, tem-se como premissa que educação é um processo de construção coletiva da libertação, já que ninguém se liberta sozinho (Freire, 1970). Deste modo, a conquista da terra deve ser acompanhada da conquista de escolas que tenham estas perspectivas para que a reforma agrária tenha sucesso.

Sendo assim, desde que ocorreu a ocupação do latifúndio da Giacomett Marodin, uma das primeiras preocupações das lideranças dos sem-terra era com a oferta de educação às crianças. Foram construídos barracos onde as escolas funcionavam provisoriamente. Com a conquista da terra, são construídas escolas para que crianças, jovens e adultos não precisem ir até as cidades para serem educados. Hoje, existem nos assentamentos colégios que contemplam as diversas etapas do ensino de $1^{\circ}$ grau. As prefeituras são responsáveis pelo Pré e pelo Ensino Básico e o estado do Paraná pelo Ensino Fundamental e pelo Ensino Médio. Nos assentamento Ireno Alves dos Santos e Marcos Freire, existem 12 escolas, destas seis são de Ensino Básico, quatro de Ensino Fundamental e duas de Ensino Médio. Dentre essas, merece destaque o Colégio Iraci Salete Strozak, que é a escola-base de todas as escolas itinerantes ${ }^{4}$ do Paraná. Além dela, também destacamos o Centro de Desenvolvimento Sustentável e Educação em Agroecologia (CEAGRO), que fica localizado próximo aos assentamentos, sendo instalado na estrutura que sobrou de uma vila montada para servir de abrigo aos trabalhadores que se dedicaram a construção da Usina Hidrelétrica de Salto Santiago, no rio Iguaçu. Neste centro de educação é dada formação técnica em agroecologia a jovens assentados. Geralmente, durante o período em que os cursos ocorrem os educandos moram no próprio colégio, como foi possível observarmos em uma das visitas a campo.

Já no assentamento Celso Furtado existem dez colégios destinados ao Pré e o Ensino Básico e mais três grandes centros onde são ofertados o Ensino Fundamental e o Ensino Médio. Esses

\footnotetext{
${ }^{4}$ São denominadas de "escolas itinerantes" as escolas que funcionam em caráter nômade nos acampamentos do MST.
} 
colégios são suficientes para que todos os moradores do assentamento que frequentam as séries do $1^{\circ}$ grau não precisem se deslocar para poder estudar.

Ressaltamos que apesar desses colégios dos três assentamentos estudados representarem uma proposta alternativa ao modelo educacional ainda podem-se notar muitos problemas neles, como a precária infraestrutura, a escassez de materiais didáticos e principalmente, a dificuldade de contratação de professores que atendam a demanda. Todavia, representam uma conquista, já que se pensa a reforma agrária como um processo que vai além da conquista da terra, atingindo outras dimensões essenciais para a vivência dos camponeses. Assim, a educação ofertada nos assentamentos é entendida como parte da dimensão política da territorialidade, porque representa uma tática de permanência na terra não só para a atualidade, como também para o futuro, no caso, os jovens.

De tal modo, nos PA's analisados a territorialidade camponesa é formada como forma de luta pela permanência na terra, através da conscientização de classe que é gerada nos assentados, principalmente pela influência do MST.

\section{O TIPO PRB}

Os assentamentos do tipo PRB são construídos como forma de compensar os passivos sofridos por agricultores dos mais variados tipos (proprietários, assalariados, arrendatários e outros) que foram expropriados pela construção de usinas hidrelétricas ou ouras obras de infraestrutura. A implantação desses assentamentos é intensificada após a elaboração do II PNRA quando é feita uma crítica a forma como as empresas de energia elétrica tinham conduzido o processe de reassentamento efetivado até então.

No Território Cantuquiriguaçu existem 05 assentamentos desse tipo. Eles foram implantados em razão da construção da Usina Hidrelétrica Governador José Rixa (Salto Caxias), no rio Iguaçu, em 1995. Com a efetivação dessa obra foram inundadas terras pertencentes a nove municípios desabrigando 1.322 famílias, totalizando 6.107 pessoas (RIMA, 1993).

Parmigiani (2006) demonstra que os primeiros conflitos ocasionados em razão da construção desta usina ocorreram ainda na década de 1980, quando surgiam os boatos de que ela estava sendo planejada para aquela região. Os sindicatos de trabalhadores rurais de Nova Prata do Iguaçu, Dois Vizinhos, Realeza, Capitão Leônidas Marques, Boa Vista da Aparecida, Capanema, Planalto e Três Barras do Paraná se uniram e escreveram uma carta direcionada à população e às autoridades do estado posicionando-se de maneira contrária à construção da barragem. Eles tomavam como referência o tratamento de desprezo que tinha sido dado aos atingidos pela construção da Usina de Itaipu e tentavam convencer os setores da sociedade envolvidos com a questão de que essa situação também poderia se reproduzir neste caso. Concomitantemente, a COPEL reunia-se com prefeitos e outras lideranças dos municípios que seriam atingidos pela construção da represa e tentavam convencê-los dos benefícios que seriam trazidos com a efetivação da obra. $\mathrm{O}$ argumento utilizado pela empresa de energia elétrica era de que a região possuía um elevado índice de pobreza e que com a construção da usina seriam realizados investimentos que poderiam minimizá-los.

Em 1990 foi criada Comissão Regional dos Atingidos por Barragem do Rio Iguaçu (CRABI), tendo como referência outras lutas que vinham sendo travadas pela Crabi do Rio Grande do 
Sul. A CRABI atuou na organização das 52 comunidades que seriam atingidas com a construção da obra. Em parceria com a CPT realizava reuniões que eram chamadas de "arrastões". Nessas reuniões eram passadas informações sobre a postura da COPEL frente à possibilidade da obra e orientações às famílias atingidas na busca pela garantia de seus direitos. A CRABI buscava esclarecer os agricultores sobre a situação de abandono na qual se encontravam as famílias que tinham sido atingidas pela construção das usinas de Salto Segredo e de Salto Osório. Muitas delas estavam vivendo em barracos de lona sem nenhuma assistência da COPEL. Com isso, os agricultores sentiam temor de que com eles o mesmo pudesse ocorrer, tomando uma postura crítica frente à construção da usina.

Entretanto, nesse período, a COPEL não reconhecia a CRABI como interlocutora das famílias que seriam atingidas com a construção. A negociação era feita diretamente com prefeitos, vereadores, padres e outras lideranças, de maneira com que as famílias, que eram as maiores interessadas em tudo o que estava acontecendo, não tinham voz ativa na discussão.

Em março de 1993, a Companhia Paranaense de Energia Elétrica (COPEL) inicia o trabalho de demarcação da área onde seria efetivado o lago, processo denominado por "piqueteamento". Isso ocorre sem um aviso prévio à CRABI e às famílias que seriam atingidas, fato que motivou a revolta dos mesmos. Em resposta, esses se organizam para a realização de um protesto e contando com pouco mais de mil pessoas ocupam o local onde as obras estavam sendo efetivadas. Com essa ocupação, os manifestantes exigiam que antes de qualquer iniciativa visando à construção da barragem, fosse feita uma negociação diretamente com a CRABI. Através dessa negociação deveriam ser estabelecidas as formas de indenização que seriam utilizadas para compensar os atingidos.

A ocupação durou 30 dias. A luta ganhou visibilidade a tal ponto de até mesmo o governador do estado do Paraná naquela época, Roberto Requião tentar intervir para a solução do entrave. Como condição para desocupar a área a famílias formularam um documento intitulado "Princípios, Diretrizes e Critérios para o Remanejamento da População Atingida", que tinha a assinatura da COPEL e que foi registrado em cartório. Ficava estabelecido que a COPEL reassentaria, além dos pequenos proprietários, também os meeiros, posseiros e arrendatários. De acordo com Schrener (2002, p. 297) dois princípios básicos eram observados neste documento, de grande importância para a territorialidade dos assentamentos aqui estudados: a) que as famílias deveriam ser relocadas ou reassentadas sempre que possível no mesmo bairro rural ou município; b) que, durante o processo de remanejamento, a produção familiar não deveria sofrer decréscimo como consequência das obras do empreendimento.

Contudo, passou-se um ano e a COPEL não havia manifestado-se quanto as indenizações, fato que motivou uma nova ocupação no canteiro de obras da barragem. Como consequência foi elaborado um novo documento e no ano de 1996 começou a política de reassentamento. Ao todo foram implantados 10 projetos, abrigando 601 famílias e ocupando uma área de 18.598 ha.

No Território Cantuquiriguaçu visitamos dois desses projetos: o Três Barras, localizado no município de Três Barras do Paraná e o Agroibema, localizado no município de Rio Bonito do Iguaçu.

Nas entrevistas percebemos que os agricultores reassentados expressam uma preocupação para que sejam reconhecidos como de origem social diferente da dos sem-terra. Eles não 
desprezam a luta travada pelo MST e os demais movimentos que são mediadores para que os camponeses tenham acesso a terra, porém, salientam que no caso deles, o que ocorre é uma indenização cedida pelo Estado. Eles já estavam na terra e não planejavam sair dela, ao contrário dos sem-terra que estão fora da terra e nela buscam entrar. Ao contrário do que ocorre com os camponeses ilhéus o que dá essa diferença a eles não é a identidade, já que eles possuem identidades diversas e sim o processo social a que foram submetidos com a construção da Usina Hidrelétrica.

Vilmar, do PRB Agroibema, logo no início do diálogo travado conosco, especificou que não gosta de ser chamado por assentado, assim como as pessoas que vivem no Agroibema e sim reassentado, já que "aqui não temos nem apoio do Incra" (Entrevista realizada em 09/08/2010). Também, Elias Costa, do PRB Três Barras fez questão de demonstrar essa distinção quando questionado se assim como grande parte dos assentados em projetos de reforma agrária os reassentados tinham acesso ao Pronaf: "Pronaf já é pros mais pequeninho, a gente tem um pouquinho mais" (Entrevista realizada em 16/03/2010).

Em ambos os casos, o que se pretendeu mostrar foi que as relações que originam os territórios dos reassentamentos de atingidos por barragens são distintas das que originam os assentamentos destinados aos sem-terra. São sujeitos distintos, mas que sofrem por serem um obstáculo à expansão do capital. Ao demonstrarem essa diferença, os reassentados entendem que o tratamento dado a eles pelo Estado deve ser diferenciado do que é concedido aos assentamentos destinados aos sem-terra. O território dos PRB's surge de uma luta diferenciada, onde o principal adversário não é o latifúndio e sim as políticas do Estado, que favorecem a expansão do capital via grandes obras de infraestrutura.

Uma das exigências feitas pelas famílias quando ocorria a negociação com a COPEL, propondo o reassentamento como forma de indenização, era a de que fosse possibilitado com que as famílias não perdessem os laços sociais estabelecidos nas comunidades. Assim, os reassentamentos deveriam ser moldados de maneira com que as famílias que viviam próximas umas das outras antes das obras da represa não perdessem esse vínculo. Isso permitiria com que, além dos vínculos afetivos, também fossem preservados os vínculos produtivos, que muitas dessas famílias possuíam. Entretanto, caso não quisessem permanecer próximas aos seus antigos vizinhos esses laços seriam rompidos.

De tal forma, os lotes foram formados de maneira com que nenhum deles tivesse menos do que 7 e mais de 24 alqueires, incluindo os $20 \%$ destinados a reserva legal. As famílias que possuíssem maior quantidade de membros teriam lotes maiores. O modelo das casas foi estabelecido por um grupo de mulheres que seriam reassentadas, buscando não concentrar as decisões sobre o modelo do reassentamento apenas em pessoas do sexo masculino.

As casas são feitas em alvenaria (Figura 05), possuindo energia elétrica, poços artesianos e fossas, que foram instaladas desde o momento da criação do reassentamento pela Copel. Assim, ao contrário do que acontece com os assentamentos que são destinados aos sem-terra, através do Incra, onde a infraestrutura muitas vezes demora anos para ser instalada, nestes projetos ela já vem pronta. Entretanto, os reassentados não vêem neste fato uma vantagem, já que antes de serem expropriados muitos possuíam condições semelhantes ou até mesmo melhores. Para estes, o reassentamento representa um retrocesso nas conquistas pessoais que já possuíam. 
No PRB Agroibema existem 53 lotes e no Três Barras, 27. Observamos que ao lado das casas construídas pela Copel têm sido construídas outras, em grande parte devido aos filhos dos reassentados que se casam. Muitas dessas casas novas são de madeira e possuem condições muito inferiores se comparadas com as casas construídas primeiramente. Isso demonstra que as condições encontradas nos reassentamentos pelos agricultores não tem sido suficientes para que propiciem aos seus ascendentes reproduzir o mesmo padrão de vida que eles possuem. No entanto, manter os filhos nos lotes é importante para que o trabalho familiar não perca intensidade.

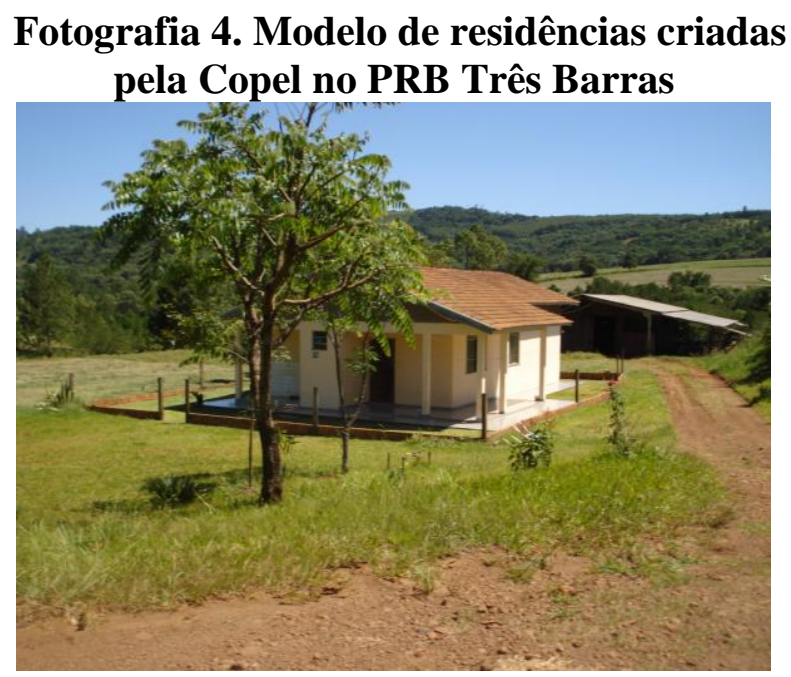

Autor:: Estevan Coca. Datas: 16/03/2010.

Foi estabelecido, já no momento em que era negociada com a Copel a indenização das famílias atingidas pela construção da Usina de Salto Santiago, que os reassentamentos deveriam ser dotados de uma área onde seriam instalados espaços de lazer e religiosidade. Assim, tanto no Agroibema quanto no Três Barras, existe um área com igrejas, salão de festas e praças esportivas (Fotografias 5, 6 e 7).

Fotografia 5. Campos de futebol e bocha do PRB Três Barras

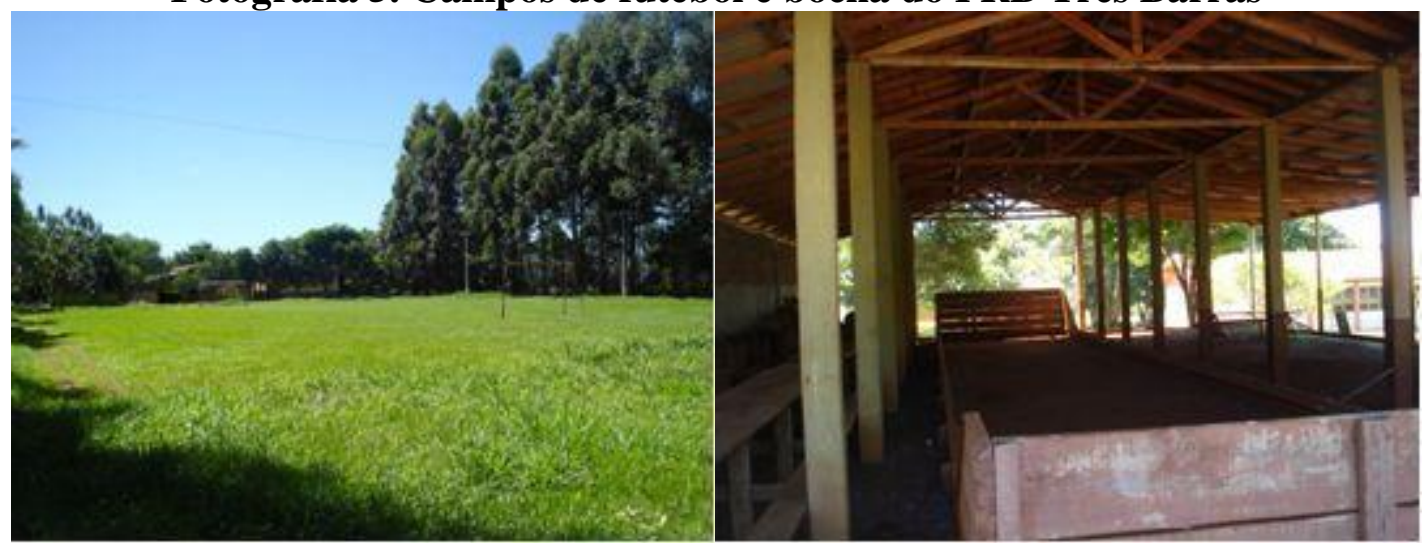

Autor: Estevan Coca. Data: 16/03/2010. 


\section{Fotografia 6. Capela dos PRB Três Barras}

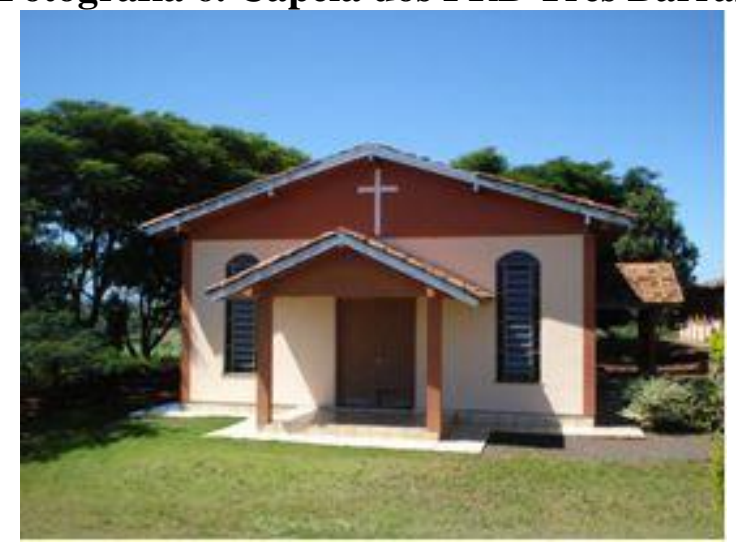

Autor: Estevan Coca. Data: 16/03/2010.

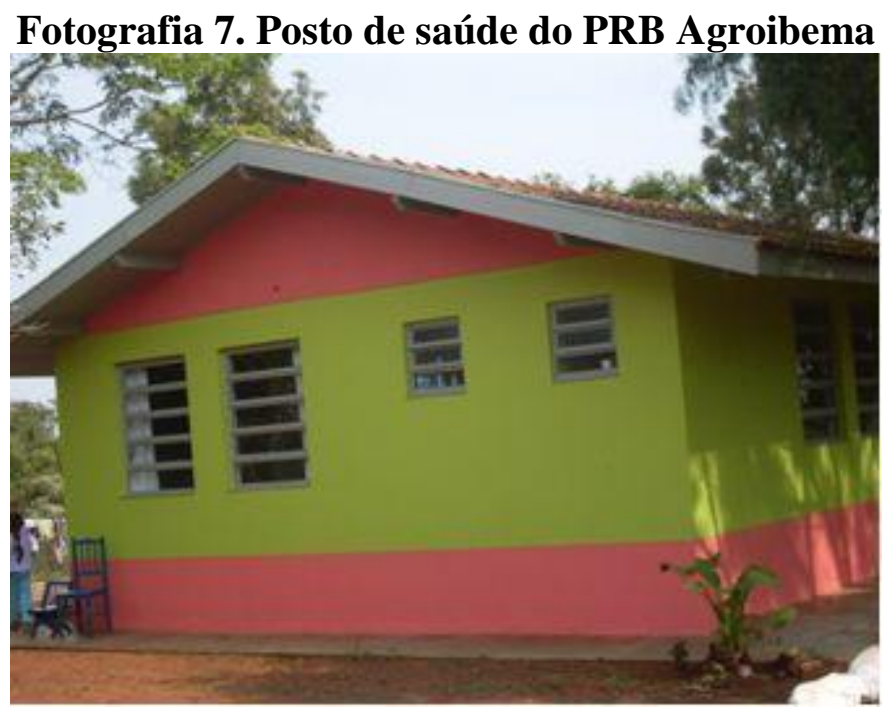

Autor: Estevan Coca. Data: 09/08/2010.

Estes exemplos demonstram, que nos reassentamentos o enfoque temporal da territorialidade é diferente se comparado com os assentamentos implantados pelo Incra. Isso porque no momento em que as famílias têm acesso a terra já existe uma estrutura mínima de lazer, saúde e religiosidade para que os reassentados sintam um impacto menor com a nova realidade que vivem após serem expropriados de suas terras e levados para outra localidade.

Nos PRB's estudados observamos que as principais produções de lavoura são o feijão, o milho e a soja. No princípio do Agroibema existiu uma proposta de fazer daquele território uma referência na produção de fumo, entretanto, os assentados relatam que houve incompatibilidade entre a empresa que comercializava a produção e as famílias, fato que fez com que a proposta não vigorasse.

Contudo, não é a lavoura a principal fonte de renda dos reassentamentos e sim o leite. No PRB Agroibema este produto é comercializado através da Cooperativa de Leite da Agricultura Familiar com Integração Solidária (COFLAP), que é uma tentativa de conquistar melhores condições de negociação deste produto junto ao mercado consumidor. No PRB Três 
Barras ele é produzido e comercializado individualmente pelas famílias junto a cooperativas e atravessadores.

Nos dois reassentamentos existem associações voltadas para variados tipos de produção, entretanto, os entrevistados frisaram que elas são de pouca representatividade. As relações de trabalho desenvolvidas nos lotes dos dois reassentamentos são majoritariamente de base familiar, configurando a produção como camponesa (Chayanov, 1974). Os entrevistados frisaram que como forma de complementar a renda, em muitas famílias existem casos de pessoas que trabalham fora do reassentamentos, especialmente os jovens. Deve-se frisar também, que nos lotes muitos produtos e criações têm como finalidade o consumo familiar e não a comercialização.

Os reassentamentos estudados tiveram origem na luta das famílias atingidas pelas obras da Usina de Salto Santiago. Estas, em uma manifestação de defesa dos seus direitos foram organizadas pela CRABI e lutaram pela justa indenização. Entretanto, mesmo com a conquista dos reassentamentos e das cartas de créditos que foram oferecidas aos que optaram por esta forma de indenização, ainda existe uma grande lacuna na organização política dos reassentados. Nenhum dos três entrevistados reconheceu que nos reassentamentos existe a participação de movimentos socioterritoriais. Constata-se que a ação da CRABI ficou restrita ao processo de conquista da terra. Após o reassentamento, as famílias optaram por ter uma postura mais desvinculada do coletivo. Isso ocorre, principalmente, devido à cultura que as famílias possuem, onde historicamente aprenderam a trabalhar individualmente em seus lotes, a gerir de maneira autônoma seus territórios. Exceções são observadas quando em alguns casos, as famílias requererem o auxílio de outras para executar algum tipo de trabalho que não pode ser executado apenas com a força de trabalho que possui.

Esse comportamento dos camponeses foi percebido durante as entrevistas, quando indagamos as lideranças sobre como é feita a gestão do assentamento. De acordo com Elias Costa, no PRB Três Barras o modelo de gestão é "[...] individual, foi tentado fazer aquela associação, mais não deu certo. Cada um toca pra si" (Entrevista realizada em 09/08/2010). No PRB Agroibema, conforme relatado por Cléber, ocorreu semelhante dificuldade:

No começo foi tentado o coletivo mais acabou não dando certo, deu rolo. Um começou a desconfiar do outro no primeiro ano e a partir do segundo ano, cada um optou individual. O que está funcionando agora, um pouco é a cooperativa de leite que foi organizada, daí, então, tamo tocando o barco (Cléber Rosalém Liderança do PRB Agroibema - 09/08/2010).

Constata-se que primeiramente, por interferência da CRABI, foram pensadas alternativas o desenvolvimento dos territórios dos assentamentos se desse através de práticas coletivas. Entretanto, como as famílias reassentadas não tinham essa cultura a prática individual prevaleceu. O coletivo, ao qual os entrevistados se referem são as práticas produtivas estimuladas pelas associações, no processo de formação dos reassentamentos.

Quando os reassentamentos foram criados pela COPEL, estabeleceu-se que primeiramente, os recursos destinados a eles seriam geridos por associações. Isso ocorreria porque a CRABI era 
impedida de fazê-lo, já que ela se trata de um movimento que não possui vínculo legal. As associações possuem estatutos e regimentos elaborados de acordo com as especificações de cada reassentamento. Schrener (2002) chama a atenção para o fato de que a COPEL tinha um interesse de que através dessas associações, parte dos investimentos feitos por ela nos reassentamentos pudesse ser devolvida. Isso ocorreria com o repasse de 250 sacas de milho por cada alqueire de terra que as famílias possuíssem em um prazo de 17 anos. A CRABI reverteu essa proposta, fazendo com que o número de sacas fosse diminuído para 10. Com isso, seriam criados fundos comuns, que seriam aplicados nas comunidades durante esse prazo. O recebimento do título fica condicionado ao cumprimento ou não desse acordo.

Nos relatos, constatamos que as associações exercem pouca influência política sobre os assentados. Em geral, são pouca famílias que se relacionam com elas, como mostra o relato de Elias Costa do PRB Três Barras:

[...] a gente montou (a associação) mais está pequeninha, uma maquinazinha mesmo, uma máquina de cortar silagem, mais nem todos eles têm parte. Vai sabê? Então nós temos, eu e o Jânio mais 4, 5 agricultores (Elias Costa-Liderança do PRB Três Barras-16/03/2010).

Fica evidente que a associação possui como finalidade a organização produtiva dos reassentados, ela foi criada com a intenção de dar um caráter coletivo às produções deste território. Entretanto, o relato demonstra que apenas algumas famílias se interessam por participar dela. Isso comprova que por parte dos reassentados não existe uma cultura que privilegie o trabalho coletivo.

Os reassentados entrevistados apontam como uma das principais dificuldades enfrentadas atualmente a questão do título de propriedade da terra. Por não terem essa situação resolvida, ainda, junto a COPEL, eles encontram empecilhos para obtenção de créditos das mais diversas modalidades. A pouca organização coletiva observada entre eles colabora para o descaso da COPEL na busca pela solução desta situação. Sobre as tentativas de reverter essa situação diz Cléber:

Nós já fizemos reunião com eles, mais, você sabe... Os caras vêm e só enrrolam. "É o ano que vem. É o ano que vem". Agora, esses dias, teve uns que foram pra Curitiba ver se resolviam isso aí, só que estão prometendo pra 2012, aí chega 2012 eles jogam mais pra frente, são promessas de político (Cléber RosalémLiderança do PRB Agroibema-09/08/2010)

Portanto, o entrevistado cita um descaso da COPEL para com a questão, fato que desperta a desconfiança dos reassentados sobre a possibilidade de se resolver esse caso em um curto espaço de tempo. Como não existe nenhum dispositivo legal regulamentando como deve se dar a titulação dos reassentado, a COPEL se aproveita para adiar a questão para prorrogar a decisão. 
Isso demonstra que a organização dos atingidos pelas obras da usina de Salto Caxias foi mais fecunda antes do reassentamento. Após o acesso a terra, muitos já não se envolvem com as lutas coletivas, dificultando o acesso a conquistas importantes, como o título de propriedade das terras, por exemplo.

\section{CONSIDERAÇÕES FINAIS}

Neste trabalho nos foi possível apresentar as territorialidades que os camponeses desenvolvem nos tipos de assentamentos do Território Cantuquiriguaçu como forma de garantir a reprodução do seu modo de vida e produção. Esses camponeses apresentam identidades diferentes, por isso, a forma como atuam na organização territorial dos assentamentos também será diferente.

A identidade é um fator que contribui para a existência de diferentes territorialidades. No assentamento do tipo PC o vínculo com a terra e a água, que é característico dos camponeses ilhéus interfere na organização territorial do assentamento, seja na disposição dos lotes, seja nas práticas produtivas dos camponeses. Nos assentamentos do tipo PA destaca-se a consciência de classe, formada/fortalecida no período de acampamento quando as práticas coletivas são incentivadas. Nos assentamentos do tipo PRB as famílias que foram compensadas por passivos sofridos pela construção da Usina Hidrelétrica de Salto Caxias demonstram ser diferentes dos agricultores sem-terra, fato que se manifesta na organização política e nas práticas produtivas.

De tal modo, a atualidade da reforma agrária brasileira não pode se interpretada sem que seja levada em consideração essa diversidade dos territórios dos assentamentos rurais e das territorialidades desenvolvidas pelos tipos de camponeses.

\section{BLIBLIOGRAFIA}

CHAYANOV, A. V. La Organizaciónde La Unidad Econômica Campesina. Buenos Aires: Ediciones Nueva Vision, 1974.

FERNANDES, B. M. Contribuição ao estudo do campesinato brasileiro: formação e territorialização do Movimento dos Trabalhadores Rurais Sem-terra-MST (1979-1999), 1999. Tese (Doutorado em Geografia Humana). Faculdade de Filosofia, Letras e Ciências Humanas, Universidade de São Paulo.

FERNANDES, B. M. Territórios da questão agrária: campesinato, reforma agrária e agronegócio. Revista Brasileira de Reforma Agrária, 2007, vol. 4, nº 2, p. 77-94.

FREIRE, P. Pedagogia do oprimido. Rio de Janeiro: Paz e Terra, 1970.

GOLDFARB, Y. A luta pela terra entre o campo e a cidade: as comunas da terra do MST, sua gestação, principais atores e desafios, 2007. Dissertação (Mestrado em Geografia Humana). Faculdade de Filosofia, Letras e Ciências Humanas, Universidade de São Paulo. 
HAMMEL, A. C., SILVA, N. J. C. e ANDREEATTA, R. Escola em movimento: a conquista dos assentamentos. Colégio Estadual Iraci Salete Strozak. Rio Bonito do Iguaçu, 2007.

IANNI, O. Colonização e contra-reforma agrária na Amazônia. Petrópolis: Vozes, 1979.

INCRA - INSTITUTO NACIONAL DE COLONIZAÇÃO E REFORMA AGRÁRIA. Plano de Consolidação do Assentamento Ireno Alves. Rio Bonito do Iguaçu e Nova Laranjeiras-PR. Brasília, 2004.

PARMIGIANI, J. Apontamentos para a história de uma luta: os atingidos pela barragem de Salto Caxias/PR. Tempo da Ciência, 2006, vol. 13, nº 26, p. 107-123.

RIMA. Relatório de Impacto Ambiental-Usina Hidrelétrica de Salto Caxias. Curitiba, 1993.

SCHIAVONI, E. Vitoreiros e monteiros: ilhéus do Litoral Norte Paulista, 1996. Dissertação (Mestrado em Geografia Humana). Faculdade de Filosofia, Letras e Ciências Humanas, Universidade de São Paulo.

SCHRENER, D. F. Entre a exclusão e a utopia: um estudo sobre os processos de organização da vida cotidiana nos assentamentos rurais. São Paulo, 2002. Tese (Doutorado em História). Programa de Pós-graduação em História Social da Universidade de São Paulo.

TAVARES DOS SANTOS, J. V. Política de colonização agrícola e o projeto camponês. In: Ensaios FEE, 1985, vol. 5, nº 2, p 127-140.

(c) Copyright Estevan Leopoldo de Freitas Coca, 2013.

(C) Copyright GeoGraphos, 2013.

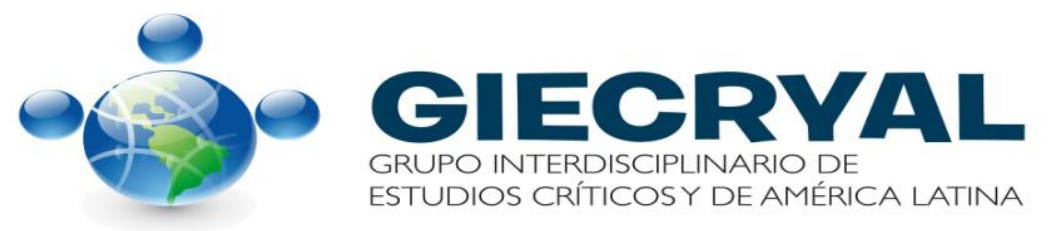

